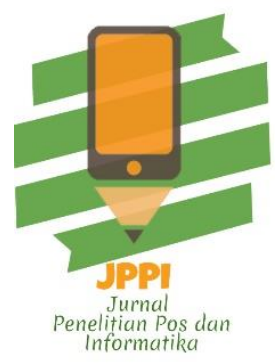

\title{
IMPLEMENTATION OF SCRUM WORK FRAMEWORK IN THE DEVELOPMENT OF QUALITY ASSURANCE INFORMATION SYSTEM
}

\section{IMPLEMENTASI SCRUM FRAMEWORK DALAM PENGEMBANGAN SISTEM INFORMASI PENJAMINAN MUTU}

\author{
Mercurius Broto Legowo', Budi Indiarto², Deden Prayitno ${ }^{3}$ \\ 1,2,3Fakultas Teknologi Informasi, Perbanas Institute-Jakarta \\ Jln. Perbanas, Karet Kuningan, Setia Budi, Jakarta Selatan, 12940 Indonesia \\ mercurius@perbanas.id ${ }^{1}$, budi.indiarto@perbanas.id ${ }^{2}$, deden@perbanas.id $^{3}$
}

Naskah Diterima: 5 June 2018; Direvisi : 26 November 2019 ; Disetujui : 9 December 2019

\begin{abstract}
Quality Assurance Information System Development is required to accellerate accreditation achievement. This Information System application is an integrated model of quality assurance information systems based on the integration of BAN-PT accreditation and ISO 9001: 2008. The purpose of this research is to develop a quality assurance information system by implementing the Scrum Framework. Scrum is one of the popular frameworks in Agile Development Methodology. In this way, the development of productivity increases significantly. In this Applied Research the Action Research approach is used. This Multi-Year Applied Research is the final research of previous studies. The results of this study presented the quality assurance information system that was produced using the complete Scrum framework. This information system is expected to contribute significantly to ISO-certified higher education in increasing the BAN-PT Accreditation assessment for their study programs.
\end{abstract}

Keywords: Accreditation of BAN-PT, Information System, ISO 9001:2008, Quality Assurance, Scrum Framework. 


\section{INTRODUCTION}

Currently, quality assurance system in Higher Education has been the subject of discussion and debates. The quality of higher education increasingly gains significance in education throughout the world (Elgobbi, 2014). Higher Education Institutions are beginning to see the quality of accreditation standards to provide and overcome global developments, outputs that meet the labor market, local and global, with high efficiency and excellence in various fields (Hamdatun et al., 2013).

According to the Ministry of Research and Technology, and Higher Education of the Republic of Indonesia, the External Quality Assurance System (SPME) is a systemic activity to assess the feasibility of study programs and/or universities in Indonesia by the National Accreditation Board for Higher Education (BAN-PT, in Indonesia) or an independent institution other than recognized universities, to oversee the implementation of higher education for and on behalf of the community as a form of public accountability (Ristek-Dikti, 2010). It also includes national bodies, such as the ministry of research, technology, and higher education, quality assurance agencies (ISO consultants) and accreditation institutions (BAN-PT), all emphasize the issue of Higher Education Institution's Quality related to inputs, processes and outputs (Al- Hemyari \& Al-Sarmi, 2017)

Accreditation Standards can improve the performance and programs of higher education institutions. According to Hamdatu et al., (2013) accreditation is also defined as a scientifically oriented activity of a company that is directed towards the advancement and improvement of higher education institutions and higher quality standards of education, including programs of study (Hamdatu et al., 2013 ). Meanwhile, according to BAN-PT (2015), study program accreditation is a comprehensive evaluation and assessment process on the said study program's commitment to quality and capacity for the implementation of three main programs that must be carried out by tertiary institutions (University Tri-Dharma in Indonesia), to determine the feasibility of its academic program (BAN-PT, 2015).

ISO 9001: 2008 is an international standard for quality management systems, which aims to ensure that the organization will provide products (goods or services) that meet specified requirements (ISO, 2018). According to Elgobbi (2014), ISO 9001: 2008 establishes criteria for QMS. This can be used by institutions, companies or organizations, large or small, regardless of the field of activity (Elgobbi, 2014). The concept of the cycle by Japanese scientists is called the Deming cycle or methodology which is known literally as Plan-Do-Check-Action (PDCA) (Brkljač, 2017).

Problems arise when an institution wishes to develop a quality assurance information system based on BAN-PT accreditation and ISO 9001: 2008 by implementing Scrum Framework, one of the Agile development methodologies. The method is considered to be very iterative, gradual and with user involvement. The information system development phase is carried out after the initial stage of integration (Broto Legowo \& Indiarto, 2017) and modeling the information system (Broto Legowo, Indiarto, \& Prayitno, 2018).

Agile Development Methodology is an iterative and gradual system development, where requirements change according to users' needs (Sharma, 2012). According to Sharma (2012), Scrum is one of the 
popular methods of Agile Development Methodology where productivity is very high.

Scrum framework that is agile for the development of adaptive systems and produce system applications which are suitable to users' needs. Based on this fact, several studies in Indonesia used Agile Development Methodology with the Scrum Framework approach (Krisnanda, 2014; Permana, 2015; Rizaldi et al., 2016).

Previous researches related to the integration of the quality assurance system model has been carried out by several researchers. Previous research made an integrated model with CMMI and ISO 9001 integration (Yoo et al., 2006; Broto Legowo, 2012). The initial stage of this research created an integrated model based on the PDCA concept in ISO 9001: 2008 quality standards and to determine effectiveness and efficiency in applying BAN-PT accreditation (Broto Legowo \& Indiarto, 2017). In the next stage, this applied research developed Information Assurance System Modeling based on the integration of BAN-PT accreditation and ISO 9001: 2008 with the EKD-CM method approach (Broto Legowo et al., 2018). Information system modeling using the EKD-CM method approach refers to research conducted by Broto Legowo (2017), the development of information system monitoring and evaluation model for bank loans (Broto Legowo, 2017).

Based on the two previous stages of research, this third-year research or the final stage of applied research aims to develop a quality assurance information system using the Agile Development Methodology approach with the Scrum Framework. The objectives of this study include:

(1) to understand how to choose Agile Development Methodology in developing this information system,

(2) to examine the selection of the Scrum method as a framework implemented in the development of this quality assurance information system.

(3) to analyze the implementation of the Scrum Framework and its stages in the complete development of the Quality Assurance Information System.

This quality assurance information system is expected to contribute significantly to ISO-certified tertiary institutions in preparing the BAN-PT Accreditation assessment for their study programs.

\subsection{Quality Assurance Information System}

BAN-PT or Higher Education National Accreditation Agency is an institution that has the authority to evaluate and assess the quality rating of a study program in a tertiary institution in Indonesia based on predetermined quality standards (BAN-PT, 2015).

ISO 9001: 2008 is an international standard for quality management systems. The ISO 9001: 2008 system focuses on the effectiveness of the continuous improvement process with the Plan-DoCheckAction concept as its main idea (ISO, 2018).

According to Brkljač, (2017), the PDCA concept goes through a four-step cycle with a brief description: Plan: Identify objectives and determine the processes needed to obtain results according to customer requirements and organizational policies. Do: Apply the process. Check: Monitor and measure processes and products, compare them with policies, objectives and requirements for products and report the results. Action: Take action to continuously improve the performance of the organization.

The Unified Model of Quality Assurance Information System (QAIS) between the BAN-PT Accreditation Standards and ISO 9001: 2008 
Standards has been successfully carried out in the research of Broto Legowo et al., (2019a). Th integration in the study was completed by using several methods of integration, including: Comparative Methods (Paulk, 1995), Mapping Methods (Mutafelija \& Stromberg, 2003), and Harmonization Model (Pardo et al., 2012). In terms of integration, a framework has been developed to link two sets of quality documents with the integration method approach, to produce a quality assurance system model whose results are very effective and efficient (Broto Legowo \& Indiarto, 2017)

\subsection{Agile Development Methodology}

The need to develop high-quality software products robust and reliable in a short time has prompted many companies to adopt the Agile software development method, most companies apply these methods especially for small-scale and relatively simple projects with successful development (Cho, Kim, \& Olsen, 2006).

According to Cho et al., (2006), agile software development is considered to be more flexible and adaptable in catering the frequently changing needs of clients, as well as manageble for small teams deployed.

Agile Development Methodology is an iterative and gradual development methodology, where requirements change according to user needs (Sharma, 2012). According to Kumar \& Bhatia (2014) the $\mathrm{s}$ the cycle stages in the system development process are: Handling Change of Requirements, Fault Detection, Increased Performance, Iterative and incremental delivery, Flexibility of Design and Improvement in Quality. This is shown in Figure 1.

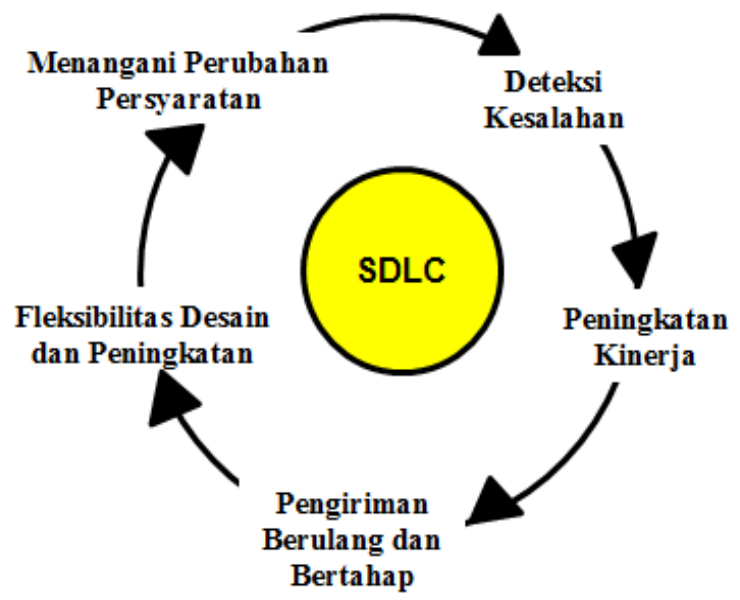

Figure 1. Agile Development Methodology

Scrum Framework is implemented in this research. Scrum is one of the popular methods of Agile Development Methodology where productivity is very high (Jeldi, Krishna, \& Chavali, 2013; Sharma, 2012).

\subsection{Scrum Framework}

Scrum is a framework for developing and maintaining complex products. Scrum is also a framework in which people can handle complex adaptive problems, while producing products productively and creatively with the highest possible value (Schwaber \& Sutherland, 2017).

According to Popli \& Chauhan (2011), Scrum is a framework that enables iterative and additional product development, enables completion of work in a timely manner, maximizes the value of what is delivered. Tasks are carried out faster and with higher quality by self-organizing teams (Popli \& Chauhan, 2011). The process flow in the Scrum framework begins with the determination of product Backlog, Sprint Planing, until it reaches the Sprint 
Retrospection stage, as shown in Figure 1

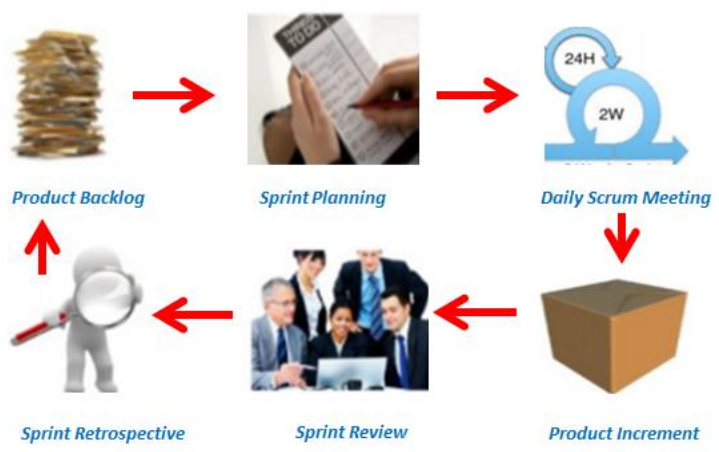

Figure 2. Flow of Proses in Scrum

Other than consisting of several Sprints, SCRUM is devided into three phases (Popli \& Chauhan, 2011), namely:

(1) Pregame, this phase includes the definition of a new release based on currently known deposits, along with an estimated schedule and cost.

(2) Games (Development Sprints Phase), this phase contains the development of new release functionality, with due regard to time, requirements, quality, cost, and competition variables. The interaction with these variables determines the end of this phase.

(3) PostGame (Closure Phase), including preparation for release, including final documentation, pre-release phased testing, and release.

\section{METHODOLOGY}

This Applied Research aims to find solutions to the problems that present in the society, industry, government as a continuation of a basic research
(RISTEK-DIKTI, 2010). This research is directed to develop applications for quality assurance information systems using Agile Software Development (Sharma, 2012).

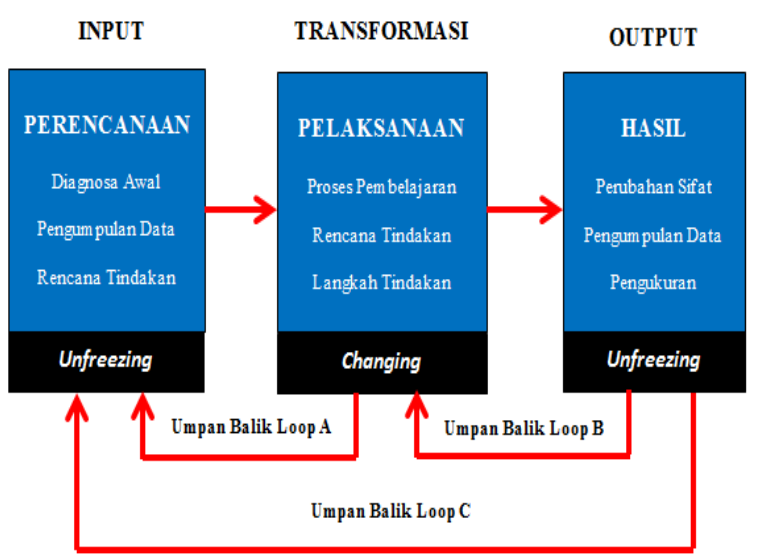

Figure 4. Action Research

The research employs the Action Research method which is used to increase productivity and flexibility by changing the process of system application development with frequently-changing inputs and display (Krisnanda, 2014). The development process of this method is shown in Figure 1. In developing this quality assurance information system application, three main stages in the Scrum Framework are carried out, namely Pregame, Game and Postgame, as shown in Figure 5. The steps for implementing the Scrum framework (Schwaber \& Sutherland, 2017), in software development are: (1) Determination of Product Backlog,

Determination of Sprint Plans, (3) Sprint Execution, (4) Daily Scrum Plans.

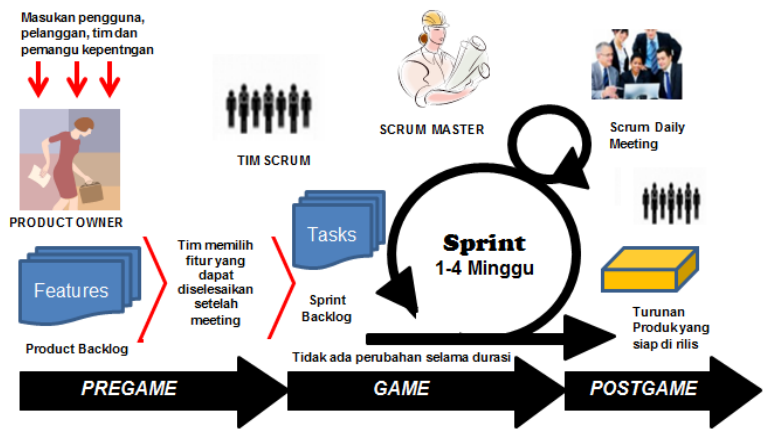


Figure 5. Stages of Scrum Framework

\section{RESULTS AND DISCUSSION}

\subsection{Research Results}

The main results that need to be analyzed in this case are the selection of system development methodology, the reasons for using the Scrum Framework and the results of the implementation of the framework being implemented and analyzed, and described in the development system.

\section{Selection of System Development Methodology:}

The system development methodology has been understood as a model used to plan, design, test, and control the development process for system applications, supplemented by a framework (Rajagopalan \& Mathew, 2016).

Table I shows a comparison between the Traditional development methodology (Waterfall) and the Agile development methodology.

Table 1. Comparison of Development Methodologies

\begin{tabular}{|l|l|l|}
\hline Features & Traditional development & Agile development \\
\hline Specification Requirements & $\begin{array}{l}\text { Required and started from } \\
\text { development }\end{array}$ & $\begin{array}{l}\text { Frequently changing } \\
\text { Requirements and specifications }\end{array}$ \\
\hline Cost incurred & Low cost & Very high cost \\
\hline Success rate & Low success rate & High success rate \\
\hline The level of risk that occurs & Increase Risk & Reduce risk \\
\hline analysis of occuring risks & At the beginning of the development & In every phase \\
\hline User Engagement & Initial involvement & High user engagement \\
\hline Flexibility & Fairly rigid & More flexible \\
\hline Development Period & Long & $\begin{array}{l}\text { Does not require long period of } \\
\text { time }\end{array}$ \\
\hline
\end{tabular}

Source: Research results, 2019

The results of Table 1 were obtained from the input of experienced system development experts.

The system development methodology using Agile is implemented through several iterations. Each iteration can occur in each phase. After the iteration is finished, the team expects comments and feedback from users (Sharma, 2012). Traditional development methodologies are inflexible and fail to respond to aggressive customer requests. In contrast, the Agile development methodology provides a set of practices that enable rapid adaptation matching of the needs of modern product development (Papadopoulos, 2015).

Differences between Agile and traditional approaches to process requirements can also cause problems (Boehm \& Turner, 2005). Based on the comparison results of the two developments, the methodology in this study determines the development of a quality assurance system using the Agile Development methodology (Broto Legowo et al., 2019b)

\section{The Application of Srum Framework:}

The Agile Development can be implemented by several methods. This study, however, will discuss two of the most widely used methodologies in the industry (Sharma, 2012).

Agile software development focuses on various aspects of the software development life cycle. Some focus on development practices (extreme programming approaches/XP Programing), while others focus on software projects management (the Scrum approach). The use of the Agile Method with Scrum is deemed very appropriate because, this method allows rapid development, leading to higher productivity. In the previous discussion, despite the 
numerous types of other Agile methods, the implementation of Scrum was very widely used in the last decade, for it focuses on managerial and development processes.
Furthermore, results of comparison between two Agile methodologies in Table 2 shows that Scrum methodology is proven to have better characteristics than the XP methodology (Broto Legowo et al., 2019b).

Table 2. Comparison between Two Agile Methods

\begin{tabular}{|l|l|l|l|}
\hline Agile Methodology & strenghts & $\begin{array}{l}\text { Development phases } \\
\text { supported }\end{array}$ & Limitation on usage \\
\hline $\begin{array}{l}\text { Extreme } \\
\text { Programming }\end{array}$ & $\begin{array}{l}\text { Focuses on users' requests } \\
\text { with low user involvement. } \\
\text { Very short iteration and } \\
\text { release. }\end{array}$ & $\begin{array}{l}\text { requirements on design, } \\
\text { code, unit tests, integration } \\
\text { tests, system tests. }\end{array}$ & $\begin{array}{l}\text { Lacking on management of } \\
\text { development practices }\end{array}$ \\
\hline $\begin{array}{l}\text { Scrum Framework } \\
\text { (SCRUM method) }\end{array}$ & $\begin{array}{l}\text { Focuses on flexibility, } \\
\text { adaptability, and high } \\
\text { productivity with a small } \\
\text { team scale, motivated from } \\
\text { the team. Integrated with } \\
\text { project management to } \\
\text { overcome deficiencies in } \\
\text { development. }\end{array}$ & $\begin{array}{l}\text { Requirementson } \\
\text { Specification, system } \\
\text { integration test }\end{array}$ & $\begin{array}{l}\text { All data, process, and coding } \\
\text { are not entirely defined. } \\
\text { Management of development } \\
\text { practices are preferred. }\end{array}$ \\
\hline
\end{tabular}

Scrum is an iterative, time-box, and incremental project management method based on "inspection and adaptation" from a simple framework (Hossain \& Babar, 2009). The use of the EKD-CM method in system modeling carried out in previous studies (Broto Legowo et al., 2018) will facilitate this system's development process, coding and all data and processes that are fully determined in the system's modeling. Based on the results in Table 2, Scrum Implementation was chosen in the development of the Quality Assurance System (Broto Legowo et al., 2019b).

\section{Results of the implementation of Srum Framework :}

By integrating the BAN-PT accreditation standard quality documents and ISO 9001: 2008, followed by running an accreditation simulation and accreditation preparation with the PDCA concept within the ISO standard. Some of the information presented in the Quality Assurance Information System, include:

\section{(1) Accreditation Standards of BAN-PT} Accreditation Standards and ISO 9001: 2008 clauses and sub-clauses,

(2) The results of the integration between the two quality documents,

(3) Evaluation of BAN-PT Accreditation and Accreditation Simulation for Study Programs, and (4) Increasing Accreditation with the PDCA concept.

\section{Feature Determination Phase in Scrum.}

The first step in implementing Scrum is the determination of features by Scrum Master based on priority scale. The Development Project Manager or the Research Coordinator Team plays the role of the Scrum Master in this case study. So as seen in Table 3, 14 features were developed. This list of features is determined, and the implementation of Scrum on the list of features is known as Product Backlog. 
Table 3. Features in Backlog

\begin{tabular}{|c|c|c|}
\hline No & Menu & Description of feature \\
\hline \multirow[t]{6}{*}{1} & \multirow[t]{6}{*}{ Data management } & Study Program \\
\hline & & User \\
\hline & & ISO clauses \\
\hline & & Accreditation Standards \\
\hline & & Assessment Element \\
\hline & & Assessment Matrix \\
\hline \multirow[t]{4}{*}{2} & \multirow{4}{*}{$\begin{array}{l}\text { Mapping and } \\
\text { Integratiobn }\end{array}$} & Mapping Form \\
\hline & & Integration Form \\
\hline & & Accreditation Simulation Form \\
\hline & & PDCA Accredition Form \\
\hline \multirow[t]{4}{*}{3} & \multirow[t]{4}{*}{ Report } & ISO Clauses and Sub-clauses \\
\hline & & ISO vs BAN-PT Mapping \\
\hline & & ISO-based SPM \\
\hline & & Assessment report \\
\hline
\end{tabular}

\section{Sprint Planning Meeting}

Sprint Planning is the first and most important Scrum activity (Neelima \& Saile, 2013). This activity is carried out in front of product owner also known as the End User. After determining the Product Backlog, a meeting is held at the beginning of each Sprint to evaluate the Product Backlog, discuss the purpose and mission of each feature as desired by the Product Owner.

In this section each team member will determine how many hours each member will spend to work on each feature. Details can be seen in Table 4.
It was decided to complete the first Sprint in four weeks considering that the team consists of only five people, and the features to work on were only in the form of templates. After working hours are determined, the team can start working on the first feature in the Product Backlog. These features are completed by team members in team work, in accordance with their respective roles in the team. All changes that occur during development must be postponed until the next Sprint. According to Neelima \& Saile (2013), there are two main artifacts for Sprint Planning, namely The Sprint Goal and The Sprint Backlog.

Table 4. Team Timetable

\begin{tabular}{|l|l|}
\hline Sprint time & 4 weeks \\
\hline Number of working days & 12 days \\
\hline
\end{tabular}

\begin{tabular}{|l|c|c|c|}
\hline \multicolumn{1}{|c|}{ Roles in Team } & $\begin{array}{c}\text { Number of working } \\
\text { days in Sprint }\end{array}$ & $\begin{array}{c}\text { Number of hours } \\
\text { per day }\end{array}$ & Total hours of first sprint \\
\hline Scrum Master & 9 days & 4 hours & 32 hours \\
\hline System Analyst & 10 days & 4 hours & 40 hours \\
\hline Programmer-1 & 12 days & 5 hours & 60 hours \\
\hline Programmer-2 & 11 days & 4 hours & hours \\
\hline Network Engineer & 5 days & 4 hours & hours \\
\hline
\end{tabular}

Source : Research results, 2019

\section{Sprint Backlog}

The determined teamwork timetable is divided into tasks for each team member, and is called the Sprint Backlog. In this section, each team member are given 
a time share to complete the features already

defined in the Product Backlog.

Details can be seen in Table 5 .

\section{Daily Scrum}

This is another activity carried out by the Scrum

Team, in which the whole team gather in the

discussion room to discuss the tasks to be carried out on the last day and the tasks to be completed

(Neelima \& Saile, 2013).

Table 5. Sprint Backlog for SIPM Application's first Feature

\begin{tabular}{|c|c|c|c|c|c|c|c|c|c|c|c|c|c|c|c|}
\hline & & & & & $A m$ & out & to & ren & Iain & ing & hou & $\overline{d d a}$ & $\sin$ & prin & \\
\hline Fitur & Task & Task & Estimated & $\mathrm{H}$ & $\mathrm{H}$ & $\mathrm{H}$ & $\mathrm{H}$ & $\mathrm{H}$ & $\mathrm{H}$ & $\mathrm{H}$ & $\mathrm{H}$ & $\mathrm{H}$ & $\mathrm{H}$ & $\mathrm{H}$ & $\mathrm{H}$ \\
\hline Backlog & & Owner & $\begin{array}{l}\text { Time } \\
\text { (hours) }\end{array}$ & 1 & 2 & 3 & 4 & 5 & 6 & 7 & 8 & 9 & 10 & 11 & 12 \\
\hline & $\begin{array}{l}\text { Business } \\
\text { Process } \\
\text { Design }\end{array}$ & $\begin{array}{l}\text { System } \\
\text { Analyst }\end{array}$ & 3 & & & & & & & & & & & & \\
\hline & $\begin{array}{l}\text { Interface } \\
\text { Design }\end{array}$ & $\begin{array}{l}\text { System } \\
\text { Analyst }\end{array}$ & 5 & & & & & & & & & & & & \\
\hline Enter Data & $\begin{array}{l}\text { Database } \\
\text { Design }\end{array}$ & $\begin{array}{l}\text { System } \\
\text { Analyst }\end{array}$ & 5 & & & & & & & & & & & & \\
\hline Management & $\begin{array}{l}\text { Coding } \\
\text { Front End }\end{array}$ & $\begin{array}{c}\text { Programmer } \\
1\end{array}$ & 20 & & & & & & & & & & & & \\
\hline & $\begin{array}{l}\text { Coding } \\
\text { Back End }\end{array}$ & $\begin{array}{c}\text { Programmer } \\
2 \\
\end{array}$ & 20 & & & & & & & & & & & & \\
\hline & Testing & $\begin{array}{l}\text { Project } \\
\text { Manager }\end{array}$ & 2 & & & & & & & & & & & & \\
\hline
\end{tabular}

In practicing performance monitoring, daily developed. By the end of each meeting, the meetings are required to be held to report tasks completion time is updated to find out the remaining completion status by each member. At this stage, not tasks to be done in the Sprint. An example of first all team members areb required to be present, only Sprint implementation on Data management input those involved specifically on the features being feature, can be seen in Table 6 .

Table 6. Daily Sprint Backlog for SIPM Application First Feature

\begin{tabular}{|c|c|c|c|c|c|c|c|c|c|c|c|c|c|c|c|}
\hline \multirow{3}{*}{ Fitur Backlog } & \multirow{3}{*}{ Tugas } & & & \multicolumn{12}{|c|}{ Jumlah Sisa Jam/hari dalam Sprint } \\
\hline & & Pemilik & Perkiraan & $\mathrm{H}$ & $\mathrm{H}$ & $\mathrm{H}$ & $\mathrm{H}$ & $\mathrm{H}$ & $\mathrm{H}$ & $\mathrm{H}$ & $\mathrm{H}$ & $\mathrm{H}$ & & $\mathrm{H}$ & $\mathrm{H}$ \\
\hline & & Tugas & Waktu (jam) & 1 & 2 & 3 & 4 & 5 & 6 & 7 & 8 & 9 & $\begin{array}{l}1 \\
0\end{array}$ & 1 & $\begin{array}{l}1 \\
2\end{array}$ \\
\hline \multirow{6}{*}{$\begin{array}{l}\text { Memasukkan } \\
\text { Pengelolaan } \\
\text { Data }\end{array}$} & $\begin{array}{l}\text { Business } \\
\text { Process } \\
\text { Design }\end{array}$ & $\begin{array}{l}\text { System } \\
\text { Analyst }\end{array}$ & 3 & 1 & 0 & 0 & 0 & 0 & 0 & 0 & 0 & 0 & 0 & 0 & 0 \\
\hline & $\begin{array}{l}\text { Interface } \\
\text { Design }\end{array}$ & $\begin{array}{l}\text { System } \\
\text { Analyst }\end{array}$ & 5 & 5 & 4 & 2 & 0 & 0 & 0 & 0 & 0 & 0 & 0 & 0 & 0 \\
\hline & $\begin{array}{l}\text { Database } \\
\text { Design }\end{array}$ & $\begin{array}{l}\text { System } \\
\text { Analyst }\end{array}$ & 5 & 5 & 5 & 5 & 5 & 3 & 0 & 0 & 0 & 0 & 0 & 0 & 0 \\
\hline & $\begin{array}{l}\text { Coding } \\
\text { Front End }\end{array}$ & $\begin{array}{l}\text { Programmer } \\
1\end{array}$ & 20 & $\begin{array}{l}2 \\
0\end{array}$ & $\begin{array}{l}2 \\
0\end{array}$ & $\begin{array}{l}2 \\
0\end{array}$ & $\begin{array}{l}1 \\
8\end{array}$ & $\begin{array}{l}1 \\
6\end{array}$ & $\begin{array}{l}1 \\
4\end{array}$ & 10 & 6 & 3 & 0 & 0 & 0 \\
\hline & $\begin{array}{l}\text { Coding } \\
\text { Back End }\end{array}$ & $\begin{array}{l}\text { Programmer } \\
2\end{array}$ & 20 & $\begin{array}{l}2 \\
0\end{array}$ & $\begin{array}{l}2 \\
0\end{array}$ & $\begin{array}{l}2 \\
0\end{array}$ & $\begin{array}{l}2 \\
0\end{array}$ & $\begin{array}{l}2 \\
0\end{array}$ & $\begin{array}{l}1 \\
8\end{array}$ & 14 & 12 & 8 & 4 & 0 & 0 \\
\hline & Testing & $\begin{array}{l}\text { Project } \\
\text { Manager }\end{array}$ & 2 & 2 & 2 & 2 & 2 & 2 & 2 & 2 & 2 & 2 & 2 & 2 & 2 \\
\hline
\end{tabular}

\section{Scrum Review}

This is the phase where the team and product owner review the entire sprint (Neelima \& Saile, 2013). Team members should discuss the functionality of the sprint developed and every suggested changes or comments are to be completed effectively in the next sprint. The Scrum Review focuses on the following aspects, namely: Sprint Goals, Achievement of tasks and Comments.

\section{Scrum Retrospective}

The main activity in scrum retrospective is when Scrum Team discusses which tasks is problematic, 
which tasks can be continued and which cannot be continued in the next sprint (Permana, 2015). The Sprint Retrospective is held after Sprint Review and prior to the next Sprint Planning. This activity is held for a maximum of three hours for a one-month Sprint (Schwaber \& Sutherland, 2017). This activity involves Scrum Review, depending on the comments received in the Review. There are 3 main points that must be determined by the team about Sprint, namely (1) start doing, (2) Stop Doing, and (3) Continue Doing. A number of other important aspects of the Scrum Framework are the Story Board and Release Burn down charts.

\section{Story Board}

Story Board is a place where all stories or user notes, tasks to be performed, and current performed task are displayed. User stories are words or sentences written by users that determine the task and also encourage the team to complete the task. This is similar to that of sticky notes posted on the Story Board. The Story Board comprises the following aspects: (1) To Do: All tasks that have not been carried out are recorded and collected, (2) In Process: All ssigned team members display the work on progress. For example "Data Management is designed by Budi", (3) To Verify: All modules and features developed must be verified. Matters that must be verified are recorded and collected in this story board. For example "BugID \# 212", (4) Done: All tasks that have been completed for a particular Sprint are recorded and collected in this section

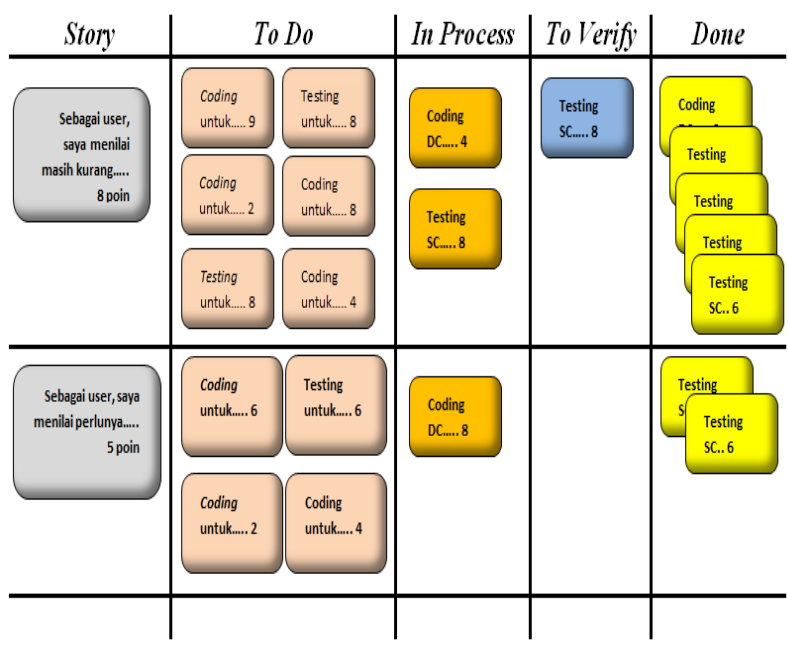

Figure 6. System development Story Board

\section{Release Burn-down Chart}

Release Burn-down Charts are charts plotted throughout the application development project by the end of each Sprint Release (Neelima \& Saile, 2013). Release Burn-down Chart is used as a tool to guide the development team to finish the Sprint on time by coding work that could potentially be sent as a product (Popli \& Chauhan, 2011). Scrum process analysis is represented in the form of a burndown chart, where the data displayed is the values in the ideal column remaining and actual tasks. The first sprint burn down chart release image is shown in Figure 7.

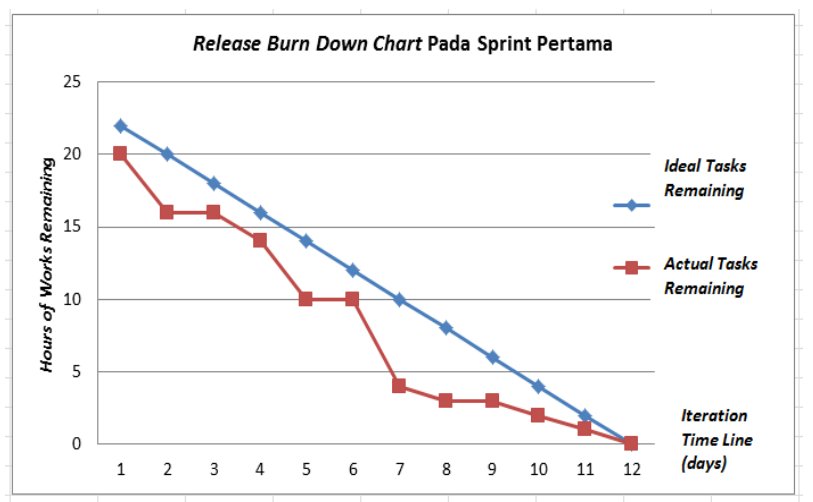

Figure 7. Release Burn-down Chart on First Feature

In Figure 7, the initial iteration of the sprint shows the actual tasks remaining to sit below the ideal line tasks remaining. In the next iteration of tasks, the 
actual tasks remaining line is always below the ideal tasks remaining. This implies that the development team gave satisfactory performance line below the ideal line. It can be concluded that the estimations for each task are in accordance with the commitment and capability of the development team. In the first sprint, all tasks are completed within timetable of the sprint..

\section{Quality Assurance Information System results:}

The main contribution resulting from the development of the Quality Assurance Information System is the better implementation of the Plan-DoCheck-Action (P-D-C-A) concept from ISO in the accreditation process. This is shown in Figure 8. In the Figure, the PDCA Accreditation Entry Sub Menu is created to have data entry on (Plan) planning, (Do) implementation, (Check) examination and (Action) action on an item of study program accreditation assessment that has certain grades with the matrix guide assessment of study program accreditation instruments. Furthermore, the system application also displays the results of a simulation to achieve improved study program accreditation. This is shown in Figure 9.

The simulation on achieving better accreditation will encourage better performance of study programs.

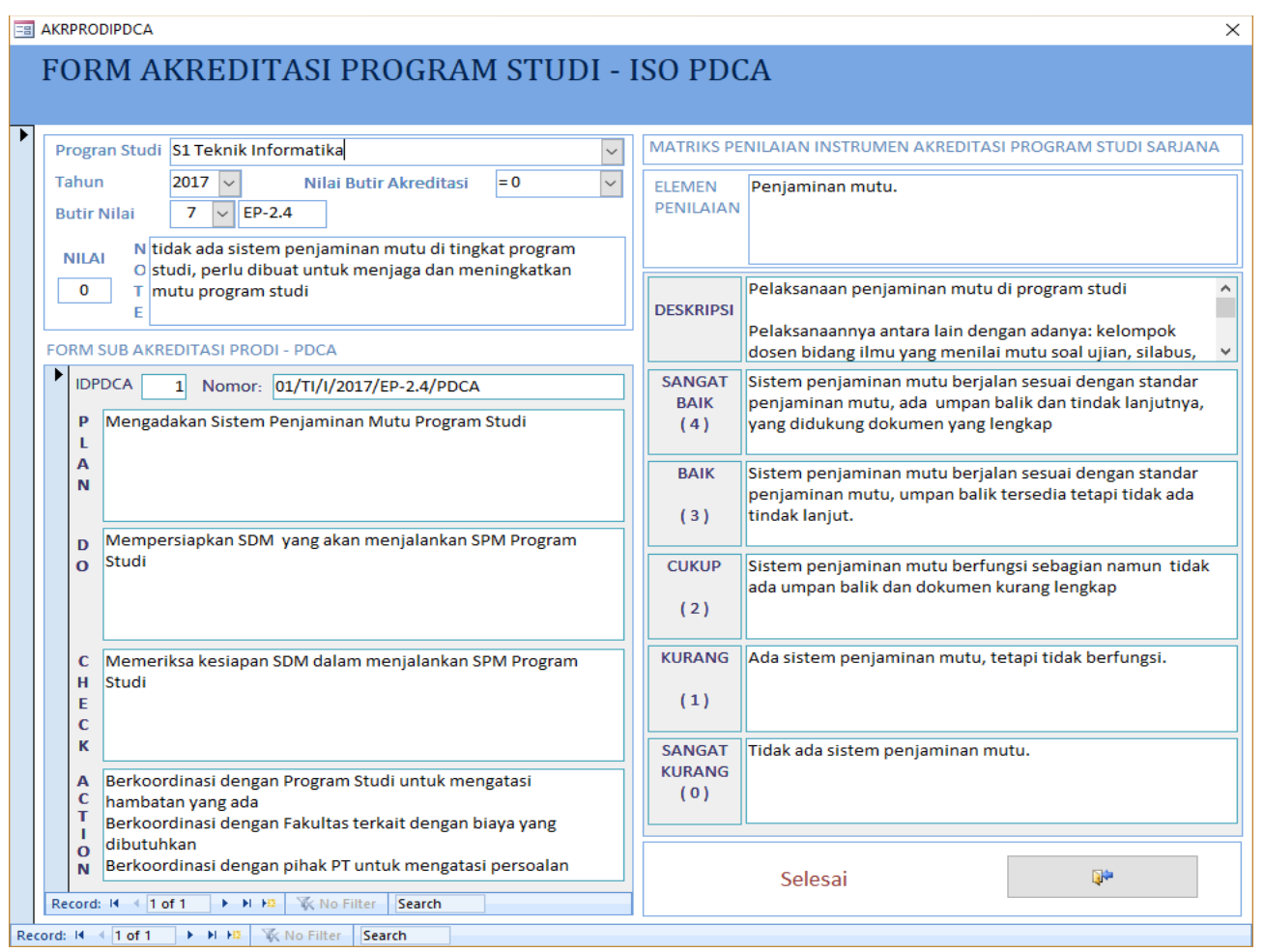

Figure 8. Application of $P-D-C-A$ concept in Quality Assurance Information System 


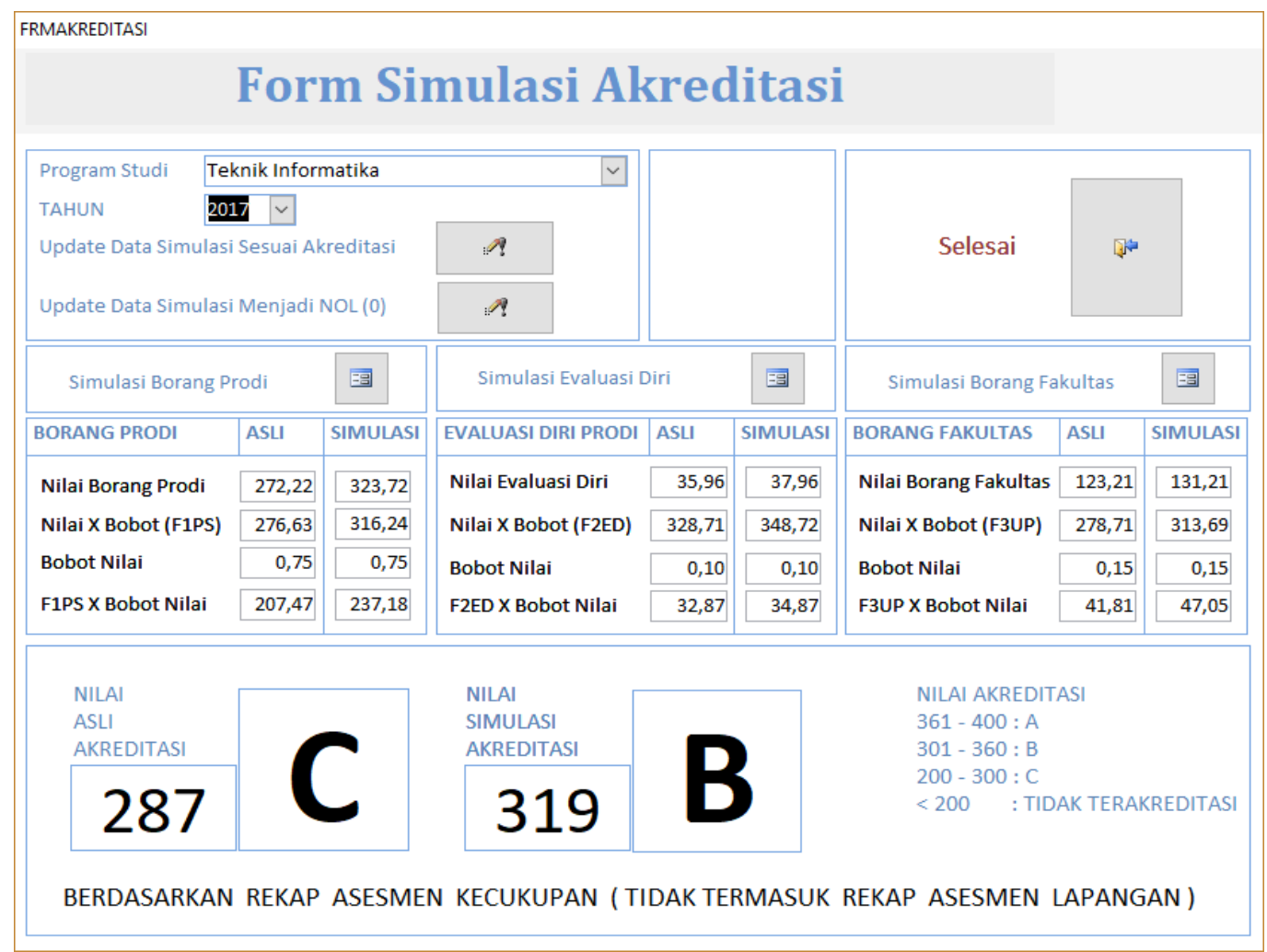

Figure 9. Simulationion achievement on quality assurance information system

Sub Menu Entry for Study Program Accreditation

Simulation was created with the aim to run a simulation on the value of accreditation based on a recap of adequacy assessment only. So it excludes the field assessment recap. At the bottom left, there are numbers and accreditation results of certain study programs in certain years, while on the right bottom are numbers and accreditation results based on simulations conducted.

\subsection{Discussion}

In this research, the system is developed using Agile Development Methodology with the Scrum framework implementation. In general, agile software development is a process that implements repetitive short cycles, actively engages users to build, prioritize, and verify needs, and relies on team's knowledge in replacing documentation (Boehm \& Turner, 2005).

The Scrum Framework offers a high level of flexibility and promises a high probability of success
(Jeldi et al., 2013). The development of the Scrum Framework implementation system or software has advantages in producing products which suit users' expectations, suitable for development of small scale systems with frequent changes, making it appropriate for the development of quality assurance system applications in this study. The Scrum method is also suitable for developing system applications with a small team size (consisting of only 5 people) whith frequent changes because the Sprint phase in Scrum can anticipate changes in the system users.

Based on the results of the analysis on the execution of each sprint and the results of the burn-down chart in the first, second and third sprints, the implementation with the Scrum Framework is the appropriate method to accelerate development period of this information system application. This is shown in the example of the results of the first sprint burndown chart, which shows the actual remaining tasks line is always below the ideal remaining task 
line.

In addition, the development of information system has theoretical, technical and managerial implications. Theoretically, this research is very appropriate to be developed with Agile Development Methodology with Scrum Framework. Technically, the implementation of information system development with the Scrum Framework is more effective and efficient compared to other system development methodologies, such as waterfalls or spirals. Meanwhile, the managerial implications of the presence of this information system is that the implementation of the Scrum Framework only requires a clear process at the planning and completion stages, while the final product, cost and completion schedule are carried out as the project is running.

In addition, the Scrum Framework maximizes the benefits of system development, including: establishment of an autonomous team, efficient product management, improved communication, and repeated and continuous monitoring.

Human resource management is important, reflected the importance of team composition on the successful development of this system application.

The study program only needs 5 people in the Scrum Team with Head of Study programs as system users.

\section{CONCLUSIONS}

The results of this Applied Research conclude that the Agile development methodology was chosen because it provides a set of practices that enable rapid adaptation according to the needs of modern application product development. The use and implementation of the Scrum Framework in the development of this quality assurance information system is done with a small scale and small team, so that it can anticipate changes that occur during the application development process. The results of the implementation of Scrum Framework in system development, one of which is the application of the P-D-C-A concept in ISO, as well as stimulation features for accreditation which will be useful to support the accreditation process of study programs.

Finally, the development prospects for further research studies can be developed by implementing this quality assurance information system by integrating it with other systems owned by ISOcertified Higher Education Institutions.

\section{ACKNOWLEDGEMENTS}

Authors would like to extend appreciations to the Directorate of Research and Community Service and the Ministry of Research, Technology and Higher Education for their assistance in granting this Multi-Years Applied Research grants in 2017, 2018, and 2019.

We also express our gratitude for the Director General of Intellectual Property - Ministry of Law and Human Rights of the Republic of Indonesia for granting the "Copyright" certificate for the second time with the number: 000163554 for this academic writing on 11 November 2019.

Thank you to the organizing committee of the 2nd International Conference of Computer and Informatics Engineering (IC2IE) for providing the opportunity to present the results of this research in this Scopus Indexed International Conference on 1011 September 2019, in Banyuwangi - East Java, also for the awards of "The Best Presenter" in the event, giving more encouragement for authors to conduct 
future research works.

\section{REFFERENCES}

Al-Hemyari, Z. A., \& Al-Sarmi, A. M. (2017). Higher Education Institutions Quality Improvement through Students and Academic Staff's Perception: Data Analysis and Robustness of the Results. International Journal for Quality Research, 11(2), 261-278. http://doi.org/10.18421/Ijqr11.02-02

BAN-PT. (2015). Permenristekdikti 32 / 2016 ttg akreditasi. Kemenristek Dikti.

Boehm, B., \& Turner, R. (2005). Management Challenges to Implementing Agile Processes in Traditional Development Organizations. IEEE Software Computer Society., 22(5), 30-39.

Brkljač, N. (2017). The Highest Hierarchical Principle For QMS In Pofit-Oriented Organizations. International Journal for Quality Research, 11(3), 643-654.

Broto Legowo, M. (2012). Maturity Model of CMMI and ISO 9001: 2008 Integration-Based Software Development in ISO Certified Organizations. Jakarta: STMIK Eresha, Jakarta.Master Thesis. Unpublished.

Broto Legowo, M. (2017). Monitoring and Evaluation Information System Modeling for Banking Credits. International Journal of Computer Science Issues, 14(5), 21-30.

Broto Legowo, M., \& Indiarto, B. (2017). Model Sistem Penjaminan Mutu Berbasis Integrasi Standar Akreditasi BAN-PT dan ISO 9001:2008. Jurnal Rekayasa Sistem Dan Teknologi Informasi, 2(1), 282-287.

Broto Legowo, M., Indiarto, B., \& Prayitno, D. (2018). Modeling Of Quality Assurance Information System For ISO-Certified Higher Education Institutions. Jurnal Penelitian Pos Dan Informatika, 8(2), 155-168. http://doi.org/10.17933/jppi.2018.080205

Broto Legowo, M., Indiarto, B., \& Prayitno, D. (2019a). A Unified Model Of Quality Assurance System For ISO-Certified. International Journal for Quality Research, In Press.

Broto Legowo, M., Indiarto, B., \& Prayitno, D. (2019b). Agile Software Methodology with Scrum for Developing Quality Assurance System. In Proceeding 2nd International Conference of Computer and Informatics Engineering (p. In Press).

Cho, J., Kim, Y., \& Olsen, D. (2006). A Case Study on the Applicability and Effectiveness of Scrum Software Development in MissionCritical and Large-Scale Projects. In Proceedings of the Twelfth Americas Conference on Information Systems, Acapulco, Mexico August 04 th -06 th 2006 (pp. 37053711).

Elgobbi, E. M. (2014). Implementing the Requirement of Quality Management System According to ISO 9001: 2008 in Higher Education Institutions: A Case Study for Sirte University in Libya. International Conference of Law, Management and Humanities (ICLMH’14), June 2014, 20-26.

Hamdatu, M. A. M., Siddiek, A. G., \& Rahman AlOlyan, F. A. (2013). Application of Quality Assurance \& Accreditation in the Institutes of Higher Education in the Arab World ( Descriptive \& Analytical Survey ). American International Journal of Contemporary Research, 3(4), 104-116.

Hossain, E., \& Babar, M. A. (2009). Using Scrum in Global Software Development: A Systematic Literature Review. In 2009 Fourth International Conference on Global Software Engineering (pp. 175-184). http://doi.org/10.1109/ICGSE.2009.25

ISO. (2018). ISO 9001:2008. In http://www.iso.org. Last Accessed: April 2018.

Jeldi, N. P., Krishna, V., \& Chavali, M. (2013). Software Development Using Agile Methodology Using Scrum Framework. International Journal of Scientific and Research Publications, 3(4), 3-5.

Krisnanda, M. (2014). Implementasi Metodologi SCRUM dalam Pembangunan Situs Harga Komoditas. Jurnal Sistem Informasi, 9(2), 149-160.

Kumar, G., \& Bhatia, P. K. (2014). Impact of Agile Methodology on Software Development Process. International Journal of Computer Technology and Electronics Engineering (IJCTEE), 2(4), 46-50.

Mutafelija, B., \& Stromberg, H. (2003). Exploring CMMI-ISO 9001:2000 Synergy when Developing a Process Improvement Strategy. SEPG 2003 Conference, (February), 165.

Neelima, E., \& Saile, N. D. S. (2013). A Study on SCRUM Agile Methodology And Its Knowledge Management Process. The 
International Journal of Engineering And Science, 2(3), 22-27.

Papadopoulos, G. (2015). Moving from traditional to agile software development methodologies also on large , distributed projects . Procedia Social and Behavioral Sciences, 175, 455-463. http://doi.org/10.1016/j.sbspro.2015.01.1223

Pardo, C., Pino, F.J., Piattini, M. (2012). Identifying methods and techniques for the harmonization of multiple process reference models. In 5th International Conference on Evaluation of Novel Approaches to Software EngineeringENASE2010, Athens, Greece (Vol. 79, pp. 8593). Retrieved from http://www.scielo.org.co/scielo.php?script=sci _arttext\&pid=S0012$73532012000200009 \&$ nrm $=$ iso

Paulk, M. C. (1995). How ISO 9001 Compares with the CMM. IEEE Software, 12(1), 74-83. http://doi.org/10.1109/52.363163

Permana, P. A. G. (2015). Scrum Method Implementation in a Software Development Project Management. International Journal of Advanced Computer Science and Applications, 6(9), 198-204.

Popli, R., \& Chauhan, N. (2011). Scrum : An Agile Framework. International Journal of Information Technology and Knowledge Management, 4(1), 147-149.
Rajagopalan, S., \& Mathew, S. K. (2016). Choice of Agile Methodologies in Software Development: A Vendor Perspective. Journal of International Technology and Information Management, 25(1), 39-54.

Ristek-Dikti. (2010). Sistem Penjaminan Mutu Perguruan Tinggi (SPM-PT). Jakarta: Kemenristek Dikti.

Rizaldi, T., Sarwo, D. P., \& Yufit, H. (2016). Implementasi Metodologi SCRUM dalam Pengembangan Sistem Pembayaran Elektronik Pada Usaha Mikro Kecil Menengah. Seminar Hasil Penelitian Dan Pengabdian Masyarakat Dana BOPTN Tahun 2016, ISBN : 978-60214917-3-7, 168-172.

Schwaber, K., \& Sutherland, J. (2017). The Scrum Guide $^{T M}$ The Definitive Guide to Scrum: The Rules of the Game. Retrieved from https://www.scrumguides.org/docs/scrumguid e/v2017/2017-Scrum-Guide-US.pdf

Sharma, S. (2012). Agile Processes and Methodologies: A Conceptual Study. International Journal on Computer Science and Engineering (IJCSE), 4(05), 892-898.

Yoo, C., Yoon, J., Lee, B., Lee, C., Lee, J., Hyun, S., \& Wu, C. (2006). A unified model for the implementation of both ISO 9001:2000 and CMMI by ISO-certified organizations. Journal of Systems and Software, 79(7), 954-961. http://doi.org/10.1016/j.jss.2005.06.042 
